Gabriella Carroll

Boston College

School of Theology and Ministry

\title{
Subversion, Substance, \& Soteriology: The Redeeming Womb in Julian of Norwich's Revelations
}

The soteriology presented in Julian of Norwich's Revelations of Divine Love has led to extensive research surrounding her belief of "universal salvation" and her liberal use of bodily images. However, there seems to be a scarcity of research focusing on how these tracks are connected - in this essay, I would like to bridge this gap. In her text, Julian states countless times that, despite Adam's Fall and the ubiquity of sin, all will ultimately "be well” for the salvation of humanity. Julian's soteriology set forth in her Revelations proves doubly radical, for it disrupts the traditional metanarratives of the Middle Ages not only by calling for a universal salvation, but also by revealing how this salvation is rooted in the female body - a stance that prefigures the postmodern theological movement.

\section{Exploring Postmodern Theology: A New Kind of Consciousness}

Julian's view of Christian salvation can distinguish her as a prefiguring practitioner of postmodern theology, as her soteriology resists what is considered "natural" in the Middle Ages. Coined by French philosopher, Francois Lyotard, the "postmodern condition" can be described as one with "incredulity toward metanarratives" — "master stories" that serve as "comprehensive explanatory frameworks" for all else to be interpreted within. ${ }^{1}$ This condition has enabled the recovery of two neglected forms of religious discourse - the "prophetic" and the "mystical"which seek to "invoke the beyond," often casting aside traditional Christian orthodoxy. ${ }^{2}$ Postmodern theologians can thus be described as "latter-day philosophical protestants" who

\footnotetext{
${ }^{1}$ Kevin J. Vanhoozer. "Theology and the Condition of Postmodernity: A Report on Knowledge (of God)." The Cambridge Companion to Postmodern Theology. (Cambridge: Cambridge UP, 2003). 9.

2 Ibid., 17-18.
} 
resist the power-infused category of the "natural."3 Postmodern theology ultimately calls for a "return of the repressed" and for an embrace of the "other," as modern systems can only master reality by excluding "what does not fit.", Specific to my discussion of Julian, postmodern feminist theology emphasizes the "liberative implications" of these ideas when applied to the category of gender ${ }^{5}$ Embracing the female body as a redemptive image, Julian can be read as calling for a "return of the repressed" through her subversion of the Christendom of Persecution, one of the controlling metannaratives that characterized the Middle Ages.

\section{II. “Bad Bodies:” Exploring a Medieval Metanarrative}

Frederick Bauerschmidt offers a historical framework of the "persecutory" medieval Christian society, demonstrating how Julian of Norwich puts forward a "metaphysical image" that moves beyond the feudal structure that characterized the Middle Ages. ${ }^{6}$ All societies are founded on a mythos, an "ideological coding that makes the political entity what it is;" for medieval society, one speculated mythos can be described as the "Christendom of Persecution."7 This mythos included strict regulation of the human body; during the Middle Ages, the boundaries and orifices of the human body were "tightly policed" in order to preserve the "purity of the soul." ${ }^{8}$ The margins of the social body were also of considerable concern, and closely moderated. Greatly influenced by Augustinian philosophy, the medieval Church strictly regulated its members, especially in regards to sin and salvation. By restricting the forgiveness of sins to within the Church, the ecclesial hierarchy effectively controlled and regulated the purity of the social body. Through addressing and regulating these potential "threats," medieval society

\footnotetext{
3 Ibid., 15.

${ }^{4}$ Vanhoozer, 16.

${ }^{5}$ Mary M. Fulkerson. "Feminist Theology." The Cambridge Companion to Postmodern Theology. (Cambridge: Cambridge UP, 2003). 110-111.

${ }^{6}$ Frederick Christian Bauerschmidt. Julian of Norwich and the Mystical Body Politic of Christ. (Notre Dame: University of Notre Dame, 1999). ix.

${ }^{7}$ Ibid., 5.

${ }^{8}$ Ibid., 64.
} 
opted for a "unified identity" of Christendom, with its purity secured by the "identification and exclusion" of sources of pollution. ${ }^{9}$

The physical female body was especially viewed as a category of social pollution, a perception heavily influenced by the lingering cultural belief of the one-sex model of human anatomy. This belief_-based on the teachings of Aristotle and Galen — asserted that the female was anatomically a "defective" and "incomplete" male. ${ }^{10}$ According to Aristotle, bodily "perfection" stems from the powers of procreation, effected by heat — a characteristic of the male form. ${ }^{11}$ If there is a lack of such "generative heat," the creation is not perfected, and a female results, with "inverted and internal" male sexual physiology. ${ }^{12}$ Due to this apparent incompleteness, the female is considered to be of a "colder and wetter" disposition, and "excessively moist."13 As a result of this excess moisture, the female constantly craved union with the heat of the male through repeated intercourse. In medical terms, this lack of sexual control came to be perceived as a vice based on "excess," while in theological terms it was viewed as a sin. ${ }^{14}$ Medical and theological views of women during the 14 th century thus served to reinforce one another, and ultimately placed women in a "category of exclusion" to be feared and regulated.

British anthropologist Mary Douglas has argued that the human body is a powerful symbol of the social body, especially with regard to boundaries. Any structure of ideas is vulnerable at its margins, for a desire to control the social body's boundaries ultimately is a

\footnotetext{
${ }^{9}$ Bauerschmidt, 67.

${ }^{10}$ Liz Herbert McAvoy. "The Motherhood Matrix in the Writing of Julian of Norwich." Authority and the Female Body in the Writings of Julian of Norwich and Margery Kempe. (Woodbridge, Suffolk: D.S. Brewer, 2004). 73.

${ }^{11}$ Elizabeth Robertson. "Medieval Medical Views of Women and Female Spirituality in Ancrene Wisse and Julian of Norwich's Showings." Feminist Approaches to the Body in Medieval Literature. (Philadelphia: U of Pennsylvania, 1993). 144.

${ }^{12}$ Ibid.

${ }^{13}$ McAvoy, 73.

${ }^{14}$ Ibid.
} 
desire to "create and maintain a certain status quo." "15 All margins are thus "dangerous:" when margins are stretched, so is the "shape of the fundamental experience" altered. ${ }^{16}$ By drawing on images of enclosure and rooting her assertion of universal salvation in the female womb-a medieval "category of exclusion"-Julian ultimately stretches and challenges the boundaries of her society, thus setting forth new mythos running counter to the traditional Christendom of Persecution of the Middle Ages.

\section{III. “All That is Made:” Once Upon a Little Hazelnut}

In chapter five of her work, Julian introduces readers to the importance of the female womb through her hazelnut image, ultimately creating an interpretive lens for her subsequent revelations to be read through. In this revelation, Julian is shown how God "clothes, enfolds, and embraces" all in God's tender love, which "completely surrounds us," never to leave us. ${ }^{17}$ Already, readers find that God's love is like a mother's womb, all-loving and all-encompassing. Julian then continues in her description, stating how God showed her a "little thing, the size of a hazelnut, on the palm of [her] hand." She ponders the apparent insignificance of the hazelnut, noting that it is "so small," and marveling how it "continued to exist and did not suddenly disintegrate." When she asks what the hazelnut is, God shows Julian that it is "all that is made," existing both "now and forever, because God loves it."18 This image of the hazelnut echoes Jesus' parable of the mustard seed in the Gospel of Matthew; though it is the "smallest of all seeds," it grows to become the "largest of garden plants and becomes a tree, so that the birds come and perch in its branches" (13:31-32). In both of these instances, we find something with seemingly "small” significance holding great implications. The "littleness" of Julian's hazelnut

\footnotetext{
${ }^{15}$ Bauerschmidt 64, 67.

${ }^{16}$ Ibid., 66.

17 Julian of Norwich. Revelations of Divine Love. (London: Penguin, 1966). 68.

${ }^{18}$ Ibid.
} 
encompassing "all that is made" can be equated with the female womb in the Middle Ages; though deemed "inferior" under the Christendom of Persecution, it ultimately acts as the vessel and catalyst for Christian salvation. This parallel drawn in chapter five between the hazelnut and the female womb ultimately foreshadows a "redeeming womb" narrative which Julian will employ throughout the rest of her text, as she reveals Mary's womb as the root of Christian salvation.

\section{The Parable of the Lord \& Servant: A Fall to Femaleness}

In chapter 51, Julian offers an allegorical interpretation of her parable of the lord and servant, which reveals how God not only opts for a "universal salvation," but also roots this salvation in Mary's womb - the female body. In this revelation, Julian sees before her "two people, a lord and a servant." The lord is sitting down quietly, "relaxed and peaceful;" the servant is standing by his lord, "humble and ready to do his bidding." The lord then looks on his servant with "rare love and tenderness," and sends him on an errand. Not only does that servant go, but he "starts off at once," running in his love "to do what his master wanted." Unexpectedly, the servant falls "headlong into a deep ditch," injures himself, and is unable to get up; but the lord regards him as blameless, for it was the servant's good will for his lord's request that ultimately caused him to fall. ${ }^{19}$ Offering an allegorical interpretation of the vision, Julian states that in the servant is represented the "second Person of the Trinity," and in the servant again, Adam, or in other words, Every Human. ${ }^{20}$ Barbara Newman of Northwestern University has recently suggested the genre of "imaginative theology" to understand writing that pursues "serious religious and theological thought through the techniques of imaginative literature,

\footnotetext{
${ }^{19}$ Julian, 141.

${ }^{20}$ Ibid., 147.
} 
especially vision, dialogue, and personification. ${ }^{, 21}$ Julian's parable seems to fit this category well, as her exploration of Adam's Fall lays the "groundwork for a new theological position"-a new understanding of sin's entrance into the world. ${ }^{22}$ This is Julian's theology of the Fall:

When Adam fell, God's Son fell. Because of the true unity which had been decreed in heaven, God's Son could not be dissociated from Adam...Adam fell from life to death, first into the depths of this wretched world, and then into hell. God's Son fell, with Adam, but into the depths of the Virgin's womb... with the intent of excusing Adam from blame both on heaven and on earth. And with a mighty arm he brought him out of hell. ${ }^{23}$

The theological implications for this passage from chapter 51 are extremely radical. Because of the "true unity" which had been "decreed in heaven," Adam and Christ are forever united; thus, since Adam falls, Christ falls as well. While Adam falls into the earth's "womb"-mortality, death, and hell—Christ falls into the Virgin's womb, the body of a female. Through the Virgin's womb, God is born human, is crucified, dies, and is resurrected. Since Adam is forever united with Christ, Adam is raised from death as well; because Adam is representative of EveryHuman, every man and woman are saved as well, for Julian states that "all the humanity that will be saved by his blessed incarnation and passion is included in Christ's humanity." ${ }^{24}$ If Christ had not fallen into the depths of the Virgin's womb, there would be no resurrection, and thus no universal salvation. Julian exhorts that it is for this reason Christ "rejoices tremendously" over his falling into the Virgin's womb, because man's “subsequent exaltation and utter happiness" results, "beyond anything we should have known" if he had not fallen. ${ }^{25}$ From this, Julian learns how God can "still behold" humans in their sin, and that it is only pain that "blames and

\footnotetext{
${ }^{21}$ Abram Van Engen. "Shifting Perspectives: Sin and Salvation in Julian's A Revelation of Love." Literature \& Theology: An International Journal of Religion, Theory, and Culture. 23.1 (2009): Arts \& Humanities Citation Index. Web. 9.

${ }^{22}$ Ibid., 10.

${ }^{23}$ Julian, 147-148.

${ }^{24}$ Ibid., 149.

${ }^{25}$ Ibid., 153.
} 
punishes. ${ }^{, 26}$ Without the womb of Mary - a category traditionally excluded in medieval society - universal salvation could not be made possible.

\section{VI. “All Will Be Well:” Stepping Beyond}

By rooting her claim of universal salvation in images of female bodily enclosure, Julian ultimately sets forth a new mythos which counters the medieval Christendom of Persecution, fostering a "return of the repressed." Though the female body proved to be "threatening" to medieval society, Julian seems to reverse this ideological coding, and instead embraces the female body as the ultimate vessel for Christian salvation through Mary's womb. The impact of this reversal is evident: the traditionally deemed "inferiority" and "impurity" of the female body is completely inverted, as Julian depicts the female body as so important and valuable that Christian salvation is rooted in its substance. It is through this "reversal" that Julian can be seen as a prefiguring founder of the postmodern theological movement and, more specifically, the mother of postmodern feminist theology. By embracing and utilizing a category traditionally excluded, Julian challenges her audience to look beyond both religious and social orthodoxy in order to see how "all will be well" through the means we least expect.

\footnotetext{
${ }^{26}$ Julian, 144.
} 


\section{Bibliography}

Bauerschmidt, Frederick Christian. Julian of Norwich and the Mystical Body Politic of Christ. Notre Dame, IN: University of Notre Dame, 1999. Print.

Fulkerson, Mary M. "Feminist Theology." The Cambridge Companion to Postmodern Theology. Cambridge: Cambridge UP, 2003. 109-25. Print.

Julian of Norwich. Revelations of Divine Love. London: Penguin, 1966. Print.

McAvoy, Liz Herbert. "The Motherhood Matrix in the Writing of Julian of Norwich." Authority and the Female Body in the Writings of Julian of Norwich and Margery Kempe. Woodbridge, Suffolk: D.S. Brewer, 2004. 64-95. Print.

Robertson, Elizabeth. "Medieval Medical Views of Women and Female Spirituality in Ancrene Wisse and Julian of Norwich's Showings." Feminist Approaches to the Body in Medieval Literature. Philadelphia: U of Pennsylvania, 1993. 142-67. Print.

Van Engen, Abram. "Shifting Perspectives: Sin and Salvation in Julian's A Revelation of Love." Literature \& Theology: An International Journal of Religion, Theory, and Culture 23.1 (2009): 1-17. Arts \& Humanities Citation Index. Web. 7 Mar. 2015.

Vanhoozer, Kevin J. "Theology and the Condition of Postmodernity: A Report on Knowledge (of God)." The Cambridge Companion to Postmodern Theology. Cambridge: Cambridge UP, 2003. 3-25. Print. 